\title{
DECOLORIZATION POTENTIAL OF IMMOBILIZED PSEUDOMONAS PUTIDA MTCC 1194 WITH LOW COST ADSORBENT FOR REACTIVE DYE
}

\author{
A.Ullhyan ${ }^{1}$, U.K. Ghosh ${ }^{2}$ \\ ${ }^{1}$ Research scholar, Department of Polymer and Process Engineering, Indian Institute of Technology \\ Roorkee,Saharanpur Campus,Saharanpur-247001,India \\ anupadpt@gmail.com,miti_anupa@rediffmail.com \\ ${ }^{2}$ Associate professor,Department of Polymer and Process Engineering, Indian Institute of Technology Roorkee, \\ Saharanpur Campus, Saharanpur-247001, India.
}

\begin{abstract}
A simultaneous adsorption and biodegradation method for removal of reactive blue-4 is reported here. The mustard stalk activated carbon (MSAC) using Pseudomonas putida MTCC1194 was applied to decolorize reactive blue-4. Batch studies were performed to evaluate the influences of various parameters; initial $\mathrm{pH}$, adsorbent dose, temperature and initial concentration, on removal of reactive blue-4. Optimum conditions for reactive blue -4 removals were found to be $\mathrm{pH} 7$, adsorbent dose $10 \mathrm{~g} /$, temperature $32^{\circ} \mathrm{C}$ at equilibrium time $360 \mathrm{~min}$ for $150 \mathrm{mg} / \mathrm{l}$ of dye concentration. Experimental data were analyzed by pseudofirst order, pseudo-second order kinetics and intra-particle diffusion model. Equilibrium isotherms for the adsorption of reactive blue 4 onto MSAC were analyzed by Freundlich, Langmuir, Temkin and Dubinin-Radushkevich (D-R). The results show that experimental data follow pseudo-second order kinetics and intra-particle diffusion model. Out of four isotherms, Langmuir was found to be best fit with experimental data $\left(R^{2}>0.97\right)$, with $70.2 \%$ removal of reactive blue 4 .
\end{abstract}

Keywords: activated carbon mustard stalk, reactive blue 4, simultaneous adsorption and biodegradation (SAB), Pseudomonas putida $* * *$

\begin{tabular}{|c|c|c|}
\hline Symbol & Description & Unit \\
\hline $1 / \mathrm{n}$ & Heterogeneity factor, dimensionless & \\
\hline $\mathrm{B}$ & Dubinin-Radushkevich model constant & $\left(\mathrm{mol}^{2} \mathrm{k} \mathrm{J}^{-2}\right)$ \\
\hline $\mathrm{B}_{1}$ & Heat of adsorption & \\
\hline $\mathrm{C}_{0}$ & Initial concentration of adsorbate in solution & $\left(\mathrm{mg} \mathrm{l}^{-1}\right)$ \\
\hline $\mathrm{C}_{\mathrm{e}}$ & Equilibrium liquid phase concentration & $\left(\mathrm{mg} \mathrm{l}^{-1}\right)$ \\
\hline $\mathrm{C}_{\mathrm{t}}$ & Concentration at time $\mathrm{t}$ & $\left(\mathrm{mg} \mathrm{l}^{-1}\right)$ \\
\hline $\mathrm{E}$ & Mean energy of sorption & $\left(\mathrm{k} \mathrm{J}^{-1} \mathrm{~mol}\right)$ \\
\hline $\mathrm{h}$ & Initial sorption rate & $\left(\mathrm{mg} \mathrm{g}^{-1} \min ^{-1}\right)$ \\
\hline I & Boundary layer & \\
\hline $\mathrm{k}$ & Rate constant of pseudo second- order sorption & $\left(\mathrm{gmg}^{-1} \min ^{-1}\right)$ \\
\hline $\mathrm{K}_{\mathrm{f}}$ & Freundlich constant & $\left(\left(\mathrm{mg} \mathrm{g}^{-1}\right)\left(\mathrm{mg} \mathrm{l}^{-1}\right)^{-1 / n}\right)$ \\
\hline $\mathrm{k}_{\mathrm{i}}$ & Rate constant of pseudo first order sorption & $\left(\min ^{-1}\right)$ \\
\hline $\mathrm{k}_{\mathrm{id} 1}$ & Intra-particle diffusion rate constant. at the first step & $\left(\mathrm{mg} \mathrm{g}^{-1} \min ^{1 / 2}\right)$ \\
\hline $\mathrm{k}_{\mathrm{id} 2}$ & Intra-particle rate constant transport at second step & $\left(\mathrm{mg} \mathrm{g}_{-1}^{-1} \min ^{1 / 2}\right)$ \\
\hline $\mathrm{K}_{\mathrm{L}}$ & Langmuir adsorption constant & $\left(1 \mathrm{mg}^{-1}\right)$ \\
\hline $\mathrm{K}_{\mathrm{T}}$ & Equilibrium binding constant & $\left(1 \mathrm{mg}^{-1}\right)$ \\
\hline $\mathrm{q}_{\mathrm{e}}$ & Sorption capacities at equilibrium & $\left(\mathrm{mg} \mathrm{g}^{-1}\right)$ \\
\hline $\mathrm{Q}_{\mathrm{m}}$ & Theoretical maximum adsorption capacity & $\left(\mathrm{mg} \mathrm{g}^{-1}\right)$ \\
\hline $\mathrm{Q}_{\mathrm{s}}$ & Theoretical monolayer saturation capacity & $\left(\mathrm{mg} \mathrm{g}^{-1}\right)$ \\
\hline $\mathrm{q}_{\mathrm{t}}$ & Sorption capacities at time $\mathrm{t}$ & $\left(\mathrm{mg} \mathrm{g}^{-1}\right)$ \\
\hline $\mathrm{R}$ & Universal gas constant & $\left(8.314 \mathrm{~J} \mathrm{~K}^{-1} \mathrm{~mol}\right)$ \\
\hline $\mathrm{R}^{2}$ & Correlation coefficient & \\
\hline $\mathrm{R}_{\mathrm{L}}$ & Separation factor, dimensionless & \\
\hline $\mathrm{T}$ & Temperature & $\left({ }^{\circ} \mathrm{C}\right)$ \\
\hline $\mathrm{t}$ & Time & Min. \\
\hline$\alpha$ & Initial sorption rate & $\left(\mathrm{mg} \mathrm{g}^{-1} \min ^{-1}\right)$ \\
\hline$\beta$ & Desorption constant & $\left(\mathrm{g} \mathrm{mg}^{-1}\right)$ \\
\hline$\varepsilon$ & Polanyi potential & \\
\hline
\end{tabular}

ABBREVIATION: 


\section{INTRODUCTION}

Dye containing wastewaters are very difficult to treat due to their high COD, BOD, suspended solids and toxic compound contents and the aesthetic issues raised by easily recognized colors. Due to large-scale production and extensive application, synthetic dyes can cause considerable environmental pollution and are serious health-risk factors [23]. The improper disposal of dyes leads to the reduction in photosynthetic activity which adversely affecting the aquatic life which cause a potential health hazard. Textile industry workers exposed to reactive dyes suffers with, changes in their immunoglobulin levels, allergic dermatitis and respiratory diseases [16].

To eliminate dyes from aqueous colored effluents, several physical, biological and chemical techniques have been used [17]. Among various methods adsorption has been found to be useful techniques as low-cost, ecofriendly for treating wastewater. The low-cost adsorbent materials obtained from agricultural wastes that have been converted to activated carbon for use in dye adsorption as reported by various researchers, i.e. olive kernels [25], Euphorbia rigida [4], oil palm trunk fiber [5] and jute fiber [18] for methylene blue removal, coconut flower for reactive red adsorption [19], bamboo dust, coconut shell, groundnut shell, rice husk and straw for removal of Congo red and silk cotton hull for reactive blue removal [20] etc.

The simultaneous adsorption-biological treatments is effective for treating dyes and organic toxic pollutants of industrial wastewaters due to minimum sludge production and improve water quality in the most economical way $[3,15]$.

Reactive dyes often used for cellulosic fabrics have environmental implications [8]. Reactive blue 4 (RB-4) an anthraquinone reactive dye, highly water soluble and nondegradable, adsorb poorly to biological solids and remain in the discharged effluents [2,17]. Therefore our aim to eliminate reactive blue- 4 by simultaneous adsorption and biodegradation by mustard stalk activated carbon (MSAC) immobilized with Pseudomonas putida MTCC 1194. The process parameters like adsorbent dose, initial concentration, contact time, temperature and $\mathrm{pH}$ have been optimized to find out percent removal of reactive blue- 4 . The kinetic, intra-particle diffusion model and adsorption isotherms, used to evaluate the experimental data.

\section{MATERIALS AND METHODS}

Activated carbon prepared from the mustard stalk by the procedure mention by Ullhyan et al. 2014 [22]. The physicochemical characteristics of MSAC were determined using standard procedures by ASTM. The surface area of activated carbon is a key factor because, like other physical-chemical characteristics, it may strongly affect the adsorption capacity of activated carbon. Nitrogen adsorption experiments at $77.15 \mathrm{~K}$ were conducted to determine the specific surface area of the mustard stalk activated carbon using an (ASAP 2010 Micrometrics) surface area analyzer. In order to investigate the surface morphology of MSAC, scanning electron microscope (Model SEM-501, Phillips, Holland) was used.

The commercial reactive blue- 4 (abbreviation: $\mathrm{RB}-4$, CI number: 61205; molecular formula: $\mathrm{C}_{23} \mathrm{H}_{12} \mathrm{C}_{12} \mathrm{~N}_{6} \mathrm{Na}_{2} \mathrm{O}_{8} \mathrm{~S}_{2}$ ) was purchased from Sigma Aldrich (Germany). An accurately weighed quantity of the dye was dissolved in double-distilled water to prepare a stock solution (1000 $\mathrm{mg} / \mathrm{l})$. The desired concentration range 50-200 mg/l was obtained by successive dilutions with double-distilled water.

\subsection{Microorganism and culture conditions}

Pseudomonas putida MTCC 1194 was obtained from Institute of Microbial Technology, Chandigarh, India. Nutrient agar medium and basal salt medium were used for microbial growth. Nutrient agar medium contained $1 \mathrm{~g}$ beef extract, $2 \mathrm{~g}$ yeast extract, $5 \mathrm{~g}$ peptone, $5 \mathrm{~g} \mathrm{NaCl}$ and $15 \mathrm{~g}$ agar in one liter distilled water. The composition of the basal salt medium (BSM) used in this experiment as the growth medium contained $1.5 \mathrm{~g} / 1 \mathrm{~K}_{2} \mathrm{HPO}_{4}, 0.5 \mathrm{~g} / 1 \mathrm{KH}_{2} \mathrm{PO}_{4}$, $0.5 \mathrm{~g} / \mathrm{l}\left(\mathrm{NH}_{4}\right)_{3} \mathrm{PO}_{4}, 0.5 \mathrm{~g} / \mathrm{l} \mathrm{NaCl}, 3 \mathrm{~g} / 1 \mathrm{Na}_{2} \mathrm{SO}_{4}, 2 \mathrm{~g} / \mathrm{l}$ Yeast extract, $0.5 \mathrm{~g} / \mathrm{l}$ Glucose, $0.002 \mathrm{~g} / \mathrm{l} \mathrm{FeSO}_{4}$ and $0.002 \mathrm{~g} / \mathrm{l}$ $\mathrm{CaCl}_{2}$.

\subsubsection{Experimental procedure}

\section{Acclimatization of culture}

The acclimatization of Pseudomonas putida (MTCC1194) in dye environment was performed as follows: the revived culture was first grown in basal salts medium (BSM) with glucose in a $250 \mathrm{ml}$ cotton-plugged conical flask for 48 hours, significant bacterial growth was observed by turning culture into milky form. Acclimatization of culture was performed in batch mode in orbital shaker at $32^{\circ} \mathrm{C}$ and 180 RPM in $250 \mathrm{ml}$ cotton-plugged conical flasks containing basal salt medium, bacterial inoculums and stock solution of dye concentration, ranging from $10 \mathrm{mg} / \mathrm{l}$ to $250 \mathrm{mg} / \mathrm{l}$, with increment of $10 \mathrm{mg} / \mathrm{l}$ in a series till the cumulative concentration in the growth medium reached $100 \mathrm{mg} / \mathrm{l}$. It was kept aside initially, until the growth of Pseudomonas putida was inhibited [10].

For batch study, experiments were conducted in $500 \mathrm{ml}$ cotton-plugged flasks containing BSM with $20 \mathrm{ml}$ inoculums of acclimatized Pseudomonas putida with dye having biomass concentration $18.72 \mathrm{mg} / \mathrm{l}$, a dye aliquot of $40 \mathrm{ml}$ of stock solution of dye and definite amount of adsorbent dose. The reaction mixture was agitated in orbital shaker at constant speed of 180 RPM. Initial concentration of reactive blue- 4 was varied between 50 to $200 \mathrm{mg} / \mathrm{l}$, having adsorbent dose varied from 2 to $12 \mathrm{~g}$. The $\mathrm{pH}$ range 2 to 9 and temperatures vary from $25{ }^{\circ} \mathrm{C}$ to $35{ }^{\circ} \mathrm{C}$, respectively. Samples were collected at definite intervals of time. All the collected samples were centrifuged at 10,000 RPM for $15 \mathrm{~min}$. The supernatant was separated and analyzed spectrophotometrically at $595 \mathrm{~nm}$ using a double beam UV/VIS spectrophotometer (Perkin-Elmer 135). Various parameters, i.e. initial concentrations of dye, adsorbent dose, $\mathrm{pH}$, contact time and temperature were studied to determine kinetic models and adsorption 
isotherm. The percentage removal of dye (eq. 1) and equilibrium adsorption uptake, $\mathrm{q}_{\mathrm{e}}(\mathrm{mg} / \mathrm{g})$, (eq.2) were calculated using the following relationships:

Dye Removal $(\%)=\frac{C_{0}-C_{t}}{C_{0}} \times 100$

Amount adsorbed $\left(\mathrm{q}_{\mathrm{e}}\right)=\frac{\left(\mathrm{C}_{0}-\mathrm{C}_{\mathrm{e}}\right) \mathrm{v}}{\mathrm{w}}$

Where $C_{o}(\mathrm{mg} / \mathrm{l})$ is the initial adsorbate concentration, $\mathrm{C}_{\mathrm{e}}$ is equilibrium concentration and $\mathrm{C}_{\mathrm{t}}$ is a concentration at time $\mathrm{t}$, $\mathrm{v}$ the volume of the solution (1) and $\mathrm{w}$ is the mass of the adsorbent (g). Statistical software Data fit 9.0 has been used for this study which utilizes the Levenberg-Marquardt method with double precision to perform nonlinear regression.

\section{RESULT AND DISCUSSION}

\subsection{Characterization of adsorbent}

Physical-chemical characteristics of mustard stalk activated carbon are presented in Table 1 and show that it contains carbon, nitrogen, sulfur, hydrogen, etc. Characterization of MSAC show BET surface area $129 \mathrm{~m}^{2} / \mathrm{g}$, BJH adsorption average pore diameter $1.505 \mathrm{~A}^{\circ}$ and $\mathrm{BJH}$ cumulative pore volume $13.56 \mathrm{cc} / \mathrm{g}$, which are good for adsorption process. Scanning electron microscopy (SEM) was used to characterize the morphology of MSAC. The SEM micrographs of fresh mustard stalk fig. 1. A, shows plain surface, but after chemical activation of mustard stalk shown in fig.1. B, having a linear type of fibers with holes and skeletal like structure in it. The well-developed pores had led to large surface area and porous structure which confirms that there is a good possibility for the adsorbate to be trapped and get adsorbed into these pores. Figure 1.C shows that holes/cavities of MSAC are filled after simultaneous adsorption and biodegradation of reactive blue-4. The characterization results, showed that low cost activated carbon prepared from mustard stalk (MSAC) using chemical activation method $\left(\mathrm{H}_{2} \mathrm{SO}_{4}\right)$ have a good indication of suitability of the mustard stalk as an adsorbent.

Table.1. Characteristics of activated carbon prepared from mustard stalk (MSAC)

\begin{tabular}{|c|c|}
\hline Properties & Value \\
\hline Ash content $(\%)$ & 6.5 \\
\hline Fixed carbon $(\%)$ & 0.95 \\
\hline Bulk density $\left(\mathrm{g} / \mathrm{cm}^{3}\right)$ & 0.37 \\
\hline Volatile matter (\%) & 19 \\
\hline Moisture (\%) & 6 \\
\hline Particle size $(\mathrm{mm})$ & $2-4$ \\
\hline Iodine number $\left(\mathrm{mg} \mathrm{g}^{-1}\right)$ & 730 \\
\hline Methylene blue number $\left(\mathrm{mg} \mathrm{g}^{-1}\right)$ & 290 \\
\hline BET surface area $\left(\mathrm{m}^{2} / \mathrm{g}\right)$ & 129 \\
\hline BJH cumulative pore volume $(\mathrm{cc} / \mathrm{g})$ & 1.505 \\
\hline $\begin{array}{l}\text { BJH adsorption average pore diameter } \\
\left(\mathrm{A}^{\circ}\right)\end{array}$ & 13.56 \\
\hline $\mathrm{pH}$ & 6.5 \\
\hline $\mathrm{C} \%$ & 74.6 \\
\hline $\mathrm{N} \%$ & 3.13 \\
\hline $\mathrm{H} \%$ & 1.4 \\
\hline $\mathrm{O} \%$ & 1.6 \\
\hline $\mathrm{S} \%$ & 1.0 \\
\hline
\end{tabular}

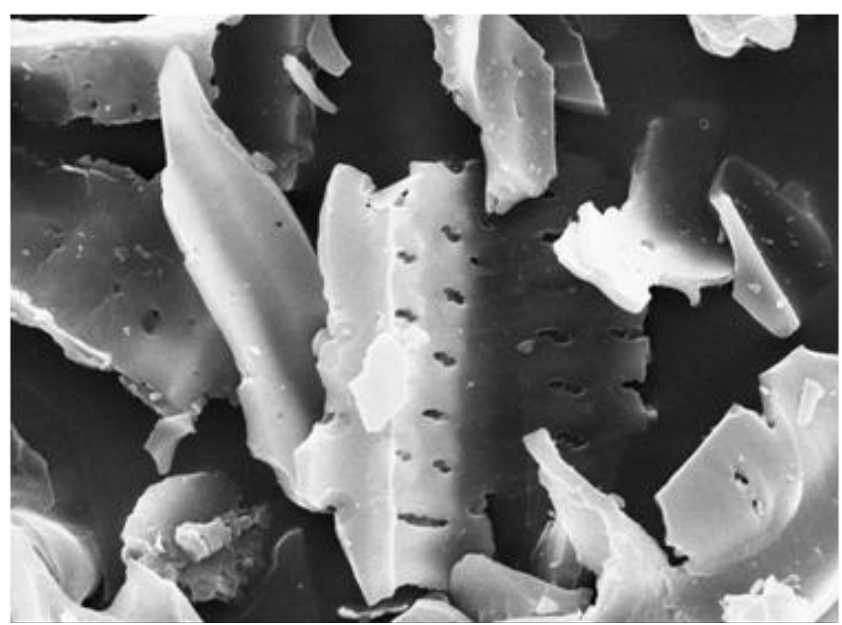

Fig-1:A SEM micrographs of fresh mustard stalk at magnification $600 \mathrm{x}$



Fig-1:B SEM micrographs of mustard stalk after activation at magnification $600 \mathrm{x}$ 




Fig-1:C SEM micrographs after SAB of Reactive blue-4 onto MSAC at magnification $600 \mathrm{x}$

\subsection{Effect of adsorbent dose}

Figure 2 reveals that removal of dye increase with increase at adsorbent dose $10 \mathrm{~g} / \mathrm{l}$, due to greater surface area and availability of more adsorption sites, but after adsorbent dose larger than $12 \mathrm{~g} / \mathrm{l}$ removal of dye almost unchanged. Beyond adsorbent dose of $10 \mathrm{~g} / \mathrm{l}$, percent removal of dye becomes almost constant indicating that the surface dye concentration and the solution dye concentration tend to reach equilibrium. So it does not make a significant effect on further increases in adsorbent dose. Hence, $10 \mathrm{~g} / \mathrm{l}$ of adsorbent dose has been used as optimum dose for this study. Similar results were obtained [21] for adsorption of dyes on low cost activated carbon.



Fig-2: Effect of adsorbent dose of removal of Reactive blue-4 onto MSAC. At $\mathrm{pH} 7$, temp. $32^{\circ} \mathrm{C}$.

\subsection{Effect of $\mathbf{p H}$}

Figure 3 shows that on either side of $\mathrm{pH} 7$, percent decolourisation decreased as the $\mathrm{pH}$ increased to acidic or alkaline range. The maximum removal of dye occurs at optimal $\mathrm{pH} 7$ and percentage removal capacity increases when the $\mathrm{pH}$ is increased from 2 to 7 , beyond $\mathrm{pH} 7$ the percentage removal of reactive blue- 4 slightly decreased. The large reduction in dye adsorption at higher basic conditions can be attributed to electrostatic repulsion between the negatively charged activated carbon and the deprotonated dye molecules. [13,14].

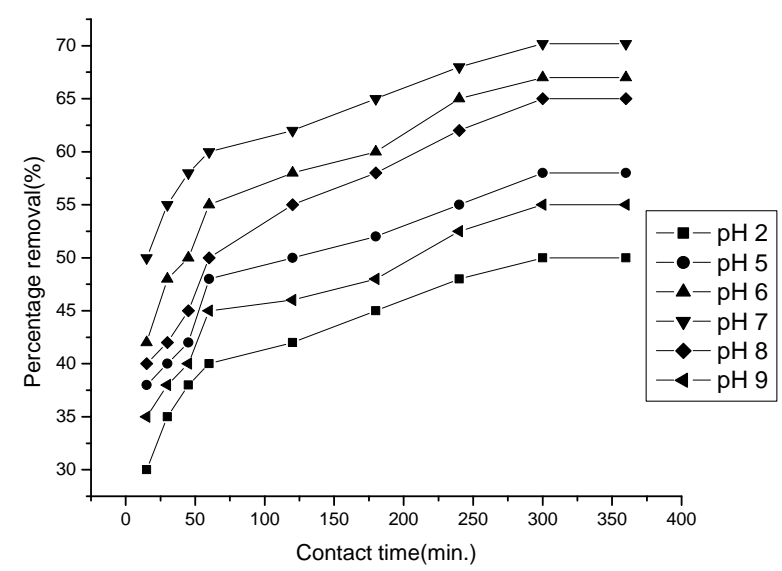

Fig-3: Effect of pH on removal of Reactive blue-4 onto MSAC. At initial conc. $150 \mathrm{mg} / \mathrm{l}$, adsorbent dose $10 \mathrm{~g} / \mathrm{l}$, temp. $32^{\circ} \mathrm{C}$

\subsection{Effect of initial dye concentration}

Figure 4 the effect of initial concentration (50-200 mg/l) of reactive blue- 4 onto MSAC show rapid adsorption in 240 min i.e. $70.2 \%$ removal and thereafter the adsorption rate decreased gradually and the adsorption reached equilibrium in about $360 \mathrm{~min}$. SAB curves are single, smooth and continuous leading to saturation and indicated the possible monolayer coverage on the surface of the adsorbent by the dye molecules [12,24]. The effect of initial dye concentrations observed in this study suggests that the increase in the initial concentration enhances the interaction between dye and MSAC [6].

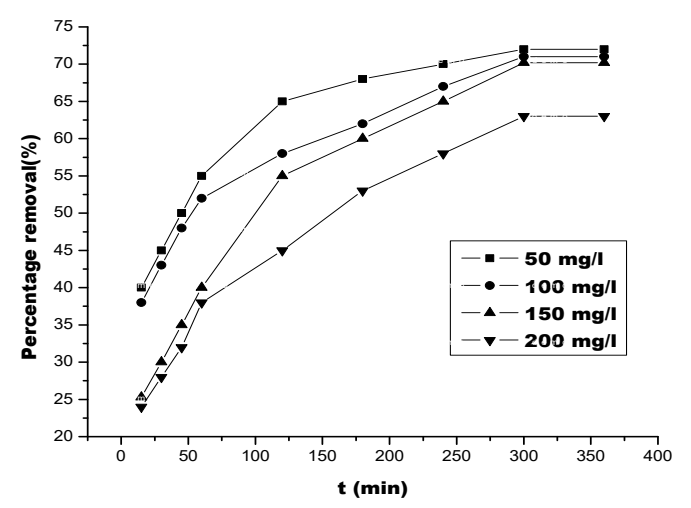

Fig-4: Effect of initial concentration on removal of Reactive blue-4 onto MSAC. At adsorbent dose $10 \mathrm{~g} / \mathrm{l}, \mathrm{pH} 7$, temp. $32^{\circ} \mathrm{C}$

\subsection{Effect Of Temperature}

Figure 5 shows that to rise in temperature from $28^{\circ} \mathrm{C}$ to $35^{\circ} \mathrm{C}$ removal of reactive blue- 4 increases. This is due to an increase in temperature, the mobility of the reactive blue- 4 ions increases and the retarding forces acting on the diffusing ions decrease, thereby increasing the sorptive 
capacity of adsorbent. Therefore, the increase in sorption capacity with an increase in temperature may be attributed to chemisorptions [9]. Beyond $35^{\circ} \mathrm{C}$ bacteria stops degradation due to slowdown of metabolic activity, then becomes dead, which hindered its biodegradation capability. Hence, for this study $32^{\circ} \mathrm{C}$ temperature was selected as the optimum temperature.

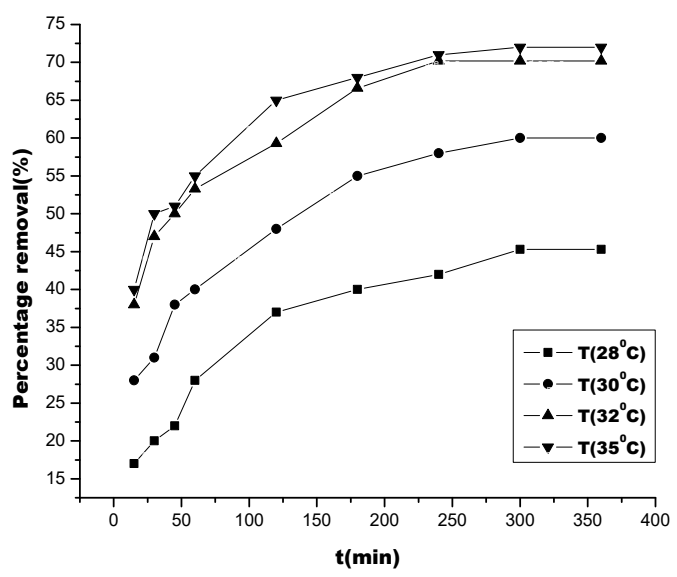

Fig-5: Effect of temperature on Reactive blue-4 removal onto MSAC. At initial conc. $150 \mathrm{mg} \mathrm{l}^{-1}$, adsorbent dose $10 \mathrm{~g}$ $1^{-1}, \mathrm{pH} 7$

\section{KINETIC AND ISOTHERMS STUDY}

To investigate the mechanism of reactive blue-4 adsorptionbiodegradation, kinetic models, that is pseudo first order, pseudo second order, and intra particle diffusion was considered to interpret the experimental data.

The pseudo-first-order model was described by Lagergren (eq. 3).

$$
\log \left(\mathrm{q}_{\mathrm{e}}-\mathrm{q}_{\mathrm{t}}\right)=\log \left(\mathrm{q}_{\mathrm{e}}\right)-\frac{\mathrm{k}_{\mathrm{i}}}{2.303} \mathrm{t}
$$

Where $\mathrm{q}_{\mathrm{e}}$ and $\mathrm{q}_{\mathrm{t}}$ refer to the amount of dye adsorbed (mg/g) at equilibrium and at any time, $\mathrm{t}(\mathrm{min})$, respectively, and $\mathrm{k}_{\mathrm{i}}$ are the equilibrium rate constant of pseudo-first-order adsorption $\left(\min ^{-1}\right)$. The values of $\log \left(\mathrm{q}_{\mathrm{e}}-\mathrm{q}\right)$ were linearly correlated with it. As shown in Table 2, pseudo-first order equation did not fit well for most of the range of concentrations under study with lower correlation coefficient $\left(\mathrm{R}^{2}\right.$ 0.562). For this reason, the Lagergren expression cannot be applied to the entire process of adsorption-biodegradation of reactive blue-4 onto MSAC.

The pseudo second order chemi-sorption kinetic rate equation is expressed as:

$\frac{\mathrm{t}}{\mathrm{q}_{\mathrm{t}}}=\frac{1}{\mathrm{kq}_{\mathrm{e}}^{2}}+\frac{1}{\mathrm{q}_{\mathrm{e}}} \mathrm{t}$

Where, $\mathrm{q}_{\mathrm{e}}$ and $\mathrm{q}_{\mathrm{t}}$ are the sorption capacities at equilibrium and at time $\mathrm{t}$, respectively, and $\mathrm{k}$ is the rate constant of pseudo second order sorption. The initial sorption rate $h$, as $\mathrm{q}_{\mathrm{t}} / \mathrm{t} \rightarrow 0$, can be defined as:

$\mathrm{h}=\mathrm{kq}_{\mathrm{e}}^{2}$
Hence, eq. (5) could be written as:

$$
\frac{\mathrm{t}}{\mathrm{q}_{\mathrm{t}}}=\frac{1}{\mathrm{~h}}+\frac{1}{\mathrm{q}_{\mathrm{e}}} \mathrm{t}
$$

The slope and intercept of plot of t/q vs. $t$ were used to calculate the second-order rate constant (Fig.6). The values of the equilibrium rate constant are presented in Table 2. The correlation coefficients of all examined data were found very high $\left(R^{2} \geq 0.998\right)$. This confirms that the sorption of reactive blue-4 onto MSAC follows the pseudo-second order kinetic model. The results indicated that the rate-limiting step may be chemical sorption.

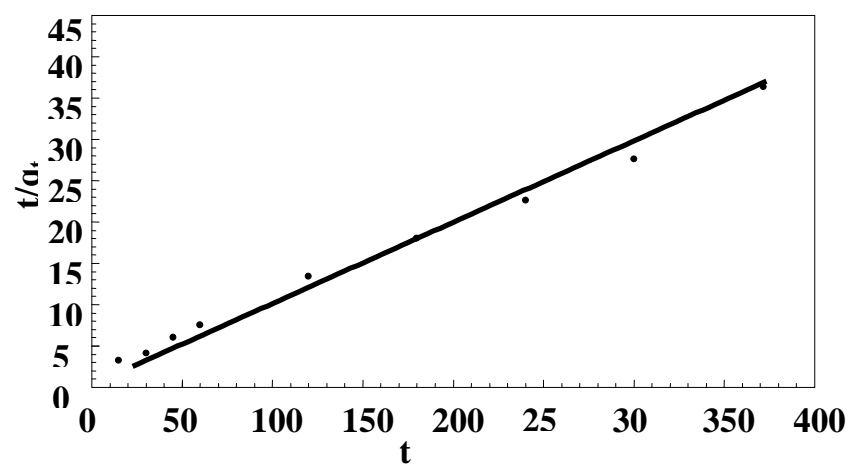

Fig-6: Pseudo-second order kinetics for Reactive blue-4 removal onto MSAC. At initial conc. $150 \mathrm{mg} / \mathrm{l}$, adsorbent dose $10 \mathrm{~g} / \mathrm{l}, \mathrm{pH} 7$, temp. $32^{\circ} \mathrm{C}$

\subsection{Intra-particle diffusion}

Pseudo-first order and second-order model could not identify the diffusion mechanism; the kinetic results were further analyzed by the intra-particle diffusion model by Weber and Morris to elucidate the diffusion mechanism. The amount of reactive blue- 4 adsorbed $\left(\mathrm{q}_{\mathrm{t}}\right)$ at a time $(\mathrm{t})$ was plotted against the square root of contact time $\left(\mathrm{t}^{0.5}\right)$ according to eq. (7)

$$
q_{t}=K_{i d} t^{\frac{1}{2}}+I
$$

Where $k_{\text {id }}$ is the intra-particle diffusion rate constant. The values of I give an idea about the thickness of the boundary layer, i.e., the larger the intercept, the greater is the boundary layer effect. Figure 7 , a plot of $\mathrm{q}_{t}$ versus $t^{1 / 2}$ is presented intra-particle diffusion of reactive blue- 4 onto MSAC. The present study indicates that the initial portion of reactive blue- 4 adsorption by MSAC may be governed by the initial intra-particle transport of dye, controlled by surface diffusion process and the later part controlled by pore diffusion. The diffusion rate was found high in the initial stages $\left(\mathrm{k}_{\mathrm{id}, 1} 4.45 \mathrm{mg} / \mathrm{g} / \mathrm{min}\right.$.) and decreased with the passage of time $\left(\mathrm{k}_{\mathrm{id}, 2} 0.014 \mathrm{mg} / \mathrm{g} / \mathrm{min}\right.$.). The values of rate parameters are given in Table 2 indicate that intra-particle diffusion step could be a rate-controlling step [11]. 


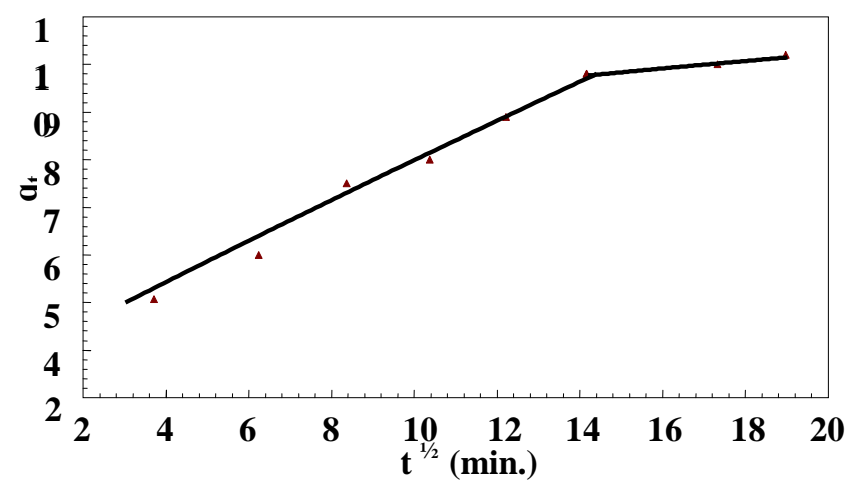

Fig-7: Weber Morris intra-particle diffusion plot for

Reactive blue-4 removal onto MSAC. At initial conc. $150 \mathrm{mg} / 1$, adsorbent dose $10 \mathrm{~g} / 1, \mathrm{pH} 7$, temp. $32^{\circ} \mathrm{C}$

\subsection{Langmuir isotherm}

The Langmuir equation is represented in the linear form as follows:

$\frac{\mathrm{C}_{\mathrm{e}}}{\mathrm{q}_{\mathrm{e}}}=\frac{1}{\mathrm{~K}_{\mathrm{L}} \mathrm{Q}_{\mathrm{m}}}+\frac{\mathrm{C}_{\mathrm{e}}}{\mathrm{Q}_{\mathrm{m}}}$

Figure 8 shows the Langmuir $\left(1 / \mathrm{C}_{\mathrm{e}} \mathrm{vs} .1 / \mathrm{q}_{\mathrm{e}}\right)$ plot of reactive blue- 4 onto MSAC. The isotherm of activated carbon is found to be linear over the whole concentration range. $Q_{m}$ is the theoretical maximum adsorption capacity $(25.8 \mathrm{mg} / \mathrm{g})$ and the correlation coefficients are extremely high, $\mathrm{R}^{2} 0.999$ as shown in Table 2. This confirms, Langmuir is a best-fit model with the experimental data.

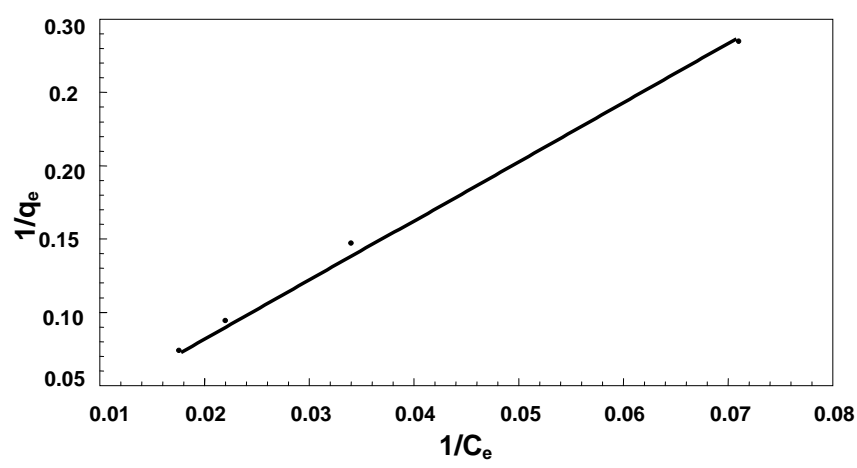

Fig-8: Langmuir Isotherm for Reactive blue-4 removal onto MSAC. At adsorbent dose $10 \mathrm{~g} / \mathrm{l}, \mathrm{pH} 7$, temp. $32^{\circ} \mathrm{C}$

\subsection{FREUNDLICH ISOTHERM}

The linear Freundlich isotherm is expressed as:

$\log \mathrm{q}_{\mathrm{e}}=\log \mathrm{K}_{\mathrm{f}}+\frac{1}{\mathrm{n}} \log \mathrm{C}_{\mathrm{e}}$

Figure 9 shows that linear plot of $\log \mathrm{q}_{\mathrm{e}}$ vs. $\log \mathrm{C}_{\mathrm{e}}$ of reactive blue-4 onto MSAC also follows freundlich isotherm. The freundlich constant value, $1 / \mathrm{n}(0.19)$ and correlation coefficients, $\mathrm{R}^{2}(0.974)$ are reported in Table 2. The value of $1 / \mathrm{n}$ has been found to lie between zero and one, indicating dye was favorably adsorbed onto MSAC. However, Freundlich isotherm is less favorable than Langmuir isotherm because $\mathrm{R}^{2}$ value is low.

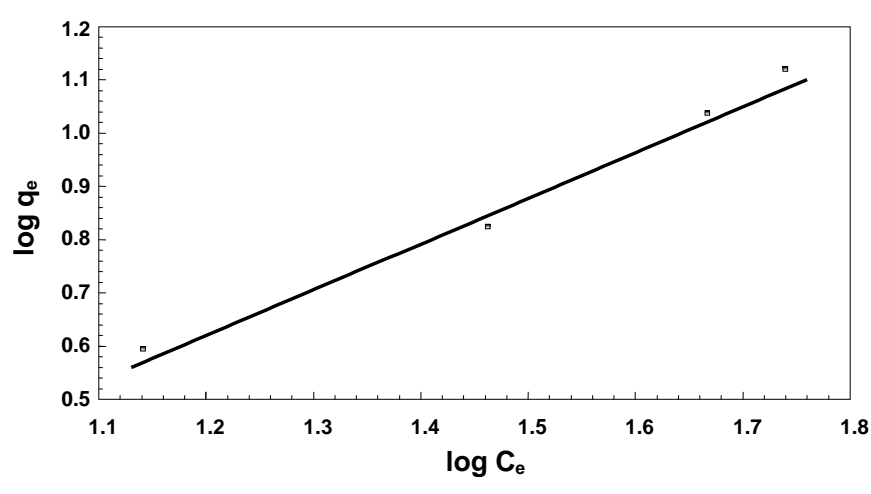

Fig-9: Freundlich Isotherm for Reactive blue-4 removal onto MSAC. At adsorbent dose $10 \mathrm{~g} / \mathrm{l}, \mathrm{pH} 7$, temp. $32^{\circ} \mathrm{C}$

\subsection{Temkin isotherm}

Temkin and Pyzhev studied the heat of adsorption and the adsorbent-adsorbate interaction on surfaces. The Temkin isotherm equation is given as:

$\mathrm{q}_{\mathrm{e}}=\mathrm{B}_{1} \ln \mathrm{K}_{\mathrm{T}}+\mathrm{B}_{1} \ln \mathrm{C}_{\mathrm{e}}$

Where, $\mathrm{B}_{1}=\mathrm{RT} / \mathrm{b}, \mathrm{T}$ is the absolute temperature, $\mathrm{R}$ is the universal gas constant $(8.314 \mathrm{~J} / \mathrm{mol})$. In eq. (10) $\mathrm{K}_{\mathrm{T}}$ is the equilibrium binding constant, and $\mathrm{B}_{1}$ is related to the heat of adsorption.

To check the suitability of Temkin model plots of $\mathrm{q}_{\mathrm{e}}$ vs. In $\mathrm{C}_{\mathrm{e}}$ has been drawn as shown in Fig.10. Values of various constants along with the correlation coefficients are given in Table 2. Moderately high $\mathrm{R}^{2}$ values $(0.888)$ confirm that Temkin isotherms provide a reasonable model for the this study.

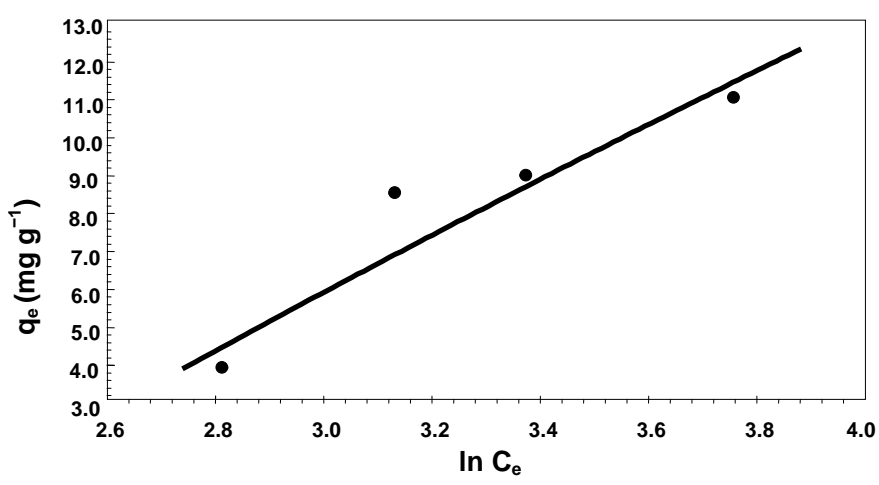

Fig-10: Temkin isotherm for removal of reactive blue-4 onto MSAC. At adsorbent dose $10 \mathrm{~g} / \mathrm{l}$, temp. $32^{\circ} \mathrm{C}$, initial conc. $150 \mathrm{mg} / \mathrm{l}, \mathrm{pH} 7$

\subsection{Dubinin-raduskevich isotherm}

Dubinin-Radushkevich isotherm [1] is generally applied to express the adsorption mechanism with a Gaussian energy distribution onto a heterogeneous surface. The linear form of Dubinin and Radushkevich isotherm equation can be expressed as:

$\ln \mathrm{q}_{\mathrm{e}}=\ln \mathrm{Q}_{\mathrm{s}}-\mathrm{B} \varepsilon^{2}$ 
Where, $\varepsilon$ is the Polanyi potential and is equal to: $\varepsilon=\mathrm{RT} \ln \left[1+\frac{1}{\mathrm{C}_{\mathrm{e}}}\right]$

The value of sorption energy, $\mathrm{E}$, can be correlated to $\beta$ using the following relationship eq. (13):

$\mathrm{E}=\frac{1}{\sqrt{-2 \beta}}$

Polanyi sorption potential, $\varepsilon$ is the work required to remove a molecule to infinity from its location in the sorption space, independent of temperature. Plot for D-R isotherm for reactive blue- 4 has been shown in fig 11 and the values of the related constants and correlation coefficients are recorded in Table 2. Poor $\mathrm{R}^{2}$ value (0.791) indicates that the $\mathrm{D}-\mathrm{R}$ isotherm cannot be used satisfactorily to fit the present experimental data [7].

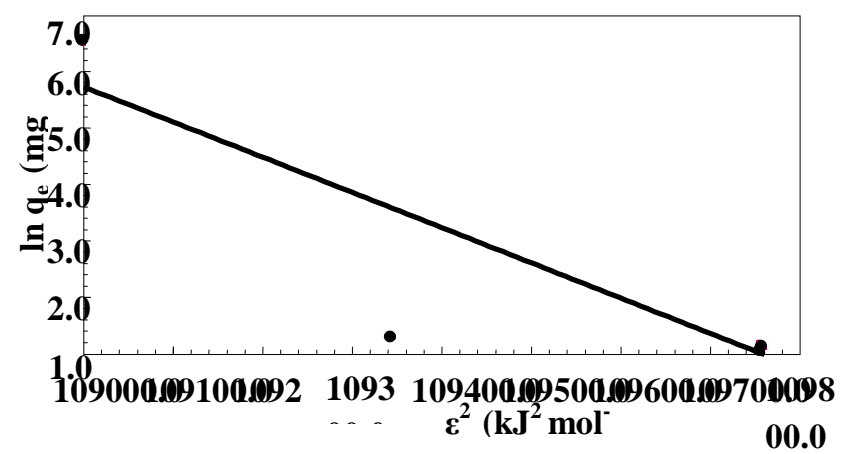

Fig-11:Dubinin-Radushkevich(D-R) isotherm for removal of Reactive blue-4 onto MSAC. At adsorbent dose $10 \mathrm{~g} / \mathrm{l}$, temp. $32^{\circ} \mathrm{C}$, initial conc. $150 \mathrm{mg} / \mathrm{l}$, pH 7

Table 2. Constant values of kinetic models and adsorption isotherms for Reactive blue-4 onto MSAC

\begin{tabular}{|c|c|c|c|c|}
\hline Pseudo-first order & $\begin{array}{l}\mathrm{k}_{\mathrm{i}} \\
0.005\end{array}$ & $\begin{array}{l}\mathrm{R}^{2} \\
0.562\end{array}$ & - & - \\
\hline $\begin{array}{l}\text { Pseudo-second } \\
\text { order }\end{array}$ & $\begin{array}{l}\mathrm{k} \\
1.45\end{array}$ & $\begin{array}{l}\mathrm{h} \\
28.2\end{array}$ & $\begin{array}{l}\mathrm{R}^{2} \\
0.998\end{array}$ & - \\
\hline $\begin{array}{l}\text { Intra-particle } \\
\text { diffusion }\end{array}$ & $\begin{array}{l}\mathrm{k}_{\mathrm{id} 1} \\
4.45 \\
\mathrm{k}_{\mathrm{id} 2} \\
0.014\end{array}$ & $\begin{array}{l}\mathrm{I} \\
88.21 \\
\mathrm{I} \\
80.2\end{array}$ & $\begin{array}{l}\mathrm{R}^{2} \\
0.995 \\
\mathrm{R}^{2} \\
0.985\end{array}$ & - \\
\hline Langmuir Isotherm & $\begin{array}{l}\mathrm{Qm}_{\mathrm{m}} \\
25.8\end{array}$ & $\begin{array}{l}\mathrm{K}_{\mathrm{L}} \\
0.08\end{array}$ & $\begin{array}{l}\mathrm{R}_{\mathrm{L}} \\
0.0013\end{array}$ & $\begin{array}{l}\mathrm{R}^{2} \\
0.9 \\
99\end{array}$ \\
\hline $\begin{array}{l}\text { Freundlich } \\
\text { Isotherm }\end{array}$ & $\begin{array}{l}\mathrm{K}_{\mathrm{f}} \\
3.19\end{array}$ & $\begin{array}{l}1 / \mathrm{n} \\
0.19\end{array}$ & $\begin{array}{l}\mathrm{R}^{2} \\
0.974\end{array}$ & - \\
\hline $\begin{array}{l}\text { Dubinin } \\
\text { Radushkevich(D- } \\
\text { R) }\end{array}$ & $\begin{array}{l}\mathrm{Q}_{\mathrm{s}} \\
13.87\end{array}$ & $\begin{array}{l}\mathrm{B} \times 10^{-6} \\
4.4\end{array}$ & $\begin{array}{l}\mathrm{E} \\
2.05\end{array}$ & $\begin{array}{l}\mathrm{R}^{2} \\
0.7 \\
91\end{array}$ \\
\hline
\end{tabular}

\begin{tabular}{|l|l|l|l|l|}
\hline Temkin Isotherm & $\mathrm{K}_{\mathrm{T}}$ & $\mathrm{B}_{1}$ & $\mathrm{R}^{2}$ & - \\
& 0.30 & 6.51 & 0.888 & \\
& & & & \\
\hline
\end{tabular}

\section{CONCLUSION}

The present study shows that the mustard stalk activated carbon (MSAC) immobilized by Pseudomonas putida MTCC 1194 is an effective adsorbent for the removal of reactive blue-4 from aqueous solution. The high removal $(70.2 \%)$ of reactive blue-4 was possible at optimum adsorbent dose $10 \mathrm{~g} / \mathrm{l}, \mathrm{pH} \mathrm{7,} \mathrm{concentration} 150 \mathrm{mg} / \mathrm{l}$ of solution at contact time of $360 \mathrm{~min}$. Mustard stalk activated carbon showed competitive properties as an adsorbent. The kinetics of reactive blue- 4 adsorption-biodegradation nicely followed second-order rate expression and demonstrated that intra particle diffusion plays a significant role in the adsorption-biodegradation mechanism. Experimental data for reactive blue- 4 on MSAC were best represented by the Langmuir isotherm. This study shows that low cost activated carbon prepared from the mustard stalk along with $P$. putida efficiently decolorized reactive blue-4 from aqueous solution. Hence simultaneous adsorption and biodegradation becomes a viable treatment for removal of dyes.

\section{REFERENCES}

[1]. Dubinin MM (1960) The potential theory of adsorption of gases and vapors for adsorbents with energetically non-uniform surface. Chem Rev. 60(2):235-266.

[2]. Epolito WJ, Lee YH, Bottomley LA, Pavlostathis S G (2005) Characterization of the textile anthraquinone dye Reactive blue 4. Dyes Pig 67:35-46.

[3]. Fu Y, Viraraghavan T (2001) Fungal decolorization of dye wastewaters: A review. Bioreso Technol 79: 251262.

[4]. Gercel O, Ozcan A, Ozcan AS, Gercel HF (2007) Preparation of activated carbon from a renewable bioplant of Euphorbia rigida by $\mathrm{H}_{2} \mathrm{SO}_{4}$ activation and its adsorption behavior in aqueous solutions. Appl. Surf. Sci 253: 4843-4852.

[5]. Hameed BH, El-Khaiary MI (2008) Batch removal of Malachite green from aqueous solutions by adsorption on oil palm trunk fiber: equilibrium isotherms and kinetic studies. J Hazar Mat 154 (1-3): 237-244.

[6]. Hema M, Arivoli S (2007) Comparative study of the adsorption kinetics and thermodynamics of dyes onto acid activated low cost carbon. Int. J. Phy. Sci 2:10-17.

[7]. Khan TA, Sangeeta S, Imran A (2011) Adsorption of Rhodamine B dye from aqueous solution onto acid activated mango (Magnifera indica) leaf powder: equilibrium, kinetic and thermodynamic studies. J Toxi Environ Heal Sci 3(10): 286-297.

[8]. Laszlo JA (1995) Electrolyte effects on hydrolyzed reactive dye binding to quaternized cellulose. Textile Chem Colo 27 (4): 25-27.

[9]. Leechart P, Nakbanpote W, Thiravetyan P (2009) Application of waste wood-shaving bottom ash for adsorption of azo reactive dye. J Env Manage 90 (2): 912-920.

[10]. Lin YH, Leu JY (2008) Kinetics of reactive azo-dye decolorization by Pseudomonas luteola in a biological activated carbon process. Biochem Engg J 39: 457- 
467.

[11]. Mall ID, Srivastava VC, Agarwal NK (2006) Removal of orange-G and methyl violet dyes by adsorption onto bagasse fly ash-kinetic study and equilibrium isotherm analyses. Dyes Pig 69: 210-223.

[12]. Malik PK (2003) Use of activated carbons prepared from sawdust and rice-husk for adsorption of acid dyes: a case study of acid yellow 36. Dyes Pig 56: 239-249.

[13]. Namasivayam C, Radhika RSS (2001) Uptake of dyes by a promising locally available agricultural solid waste: coir pith. Waste Mang 21(4): 381-387.

[14]. Newcombe G, Donati C, Drikas M, Hayes R (1996) Adsorption onto activated carbon: electrostatic and non-electrostatic interactions. Water Supp 14:129-144.

[15]. Orshansky F, Narkis N (1997) Characteristics of organics removal by pact simultaneous adsorption and biodegradation. Water. Res 31 (3): 391-398.

[16]. Park HS, Lee MK, Kim BO, Lee KJ, Roh JH, MoonYH, Hong CS (1991) Clinical and immunologic evaluations of Reactive dye-exposed workers. J Allergy and Clinical Imm 87 (3): 639-649.

[17]. Robinson T, McMullan G, Marchant R, Nigam $P$ (2001) Remediation of dyes in textile effluent: a critical review on current treatment technologies with a proposed alternative. Bioresou Technol 77: 247-255.

[18]. Senthilkumar S, Varadarajan PR, Porkodi K, Subbhuraam C V (2005) Adsorption of methylene blue onto jute fiber carbon: kinetics and equilibrium studies. J Colloid Interf Sci 284: 78-82.

[19]. Senthilkumar S, Kalaamani P, Porkodi K,Varadarajan PR, Subburaam CV (2006) Adsorption of dissolved reactive red dye from aqueous phase onto activated carbon prepared from agricultural waste. Bioresour Technol 97:1618-1625.

[20]. Thangamani KS, Sathishkumar M, Sameena Y, Vennilamani N, Kadirvelu K, Pattabi S, Yun SE (2007) Utilisation of modified silk cotton hull waste as an adsorbent for the removal of textile dye (Reactive Blue MR) from aqueous solution. Bioresour. Technol 98:1265-1269.

[21]. Theivarasu C, Mylsamy S, Sivakumar N. (2011) Kinetics, isotherm and thermodynamic studies of adsorption of Congo red from aqueous solution onto cocoa shell activated carbon, Res. J. Chem. Environ 15 (2): $34-38$

[22]. Ullhyan A, Ghosh UK (2014) Removal of 2,4Dichlorophenol by simultaneous adsorption and biodegradation (SAB) using low cost adsorbent. Global Nest, J. 16(4):616-627.

[23]. Vinu R, Madras G (2009) Kinetics of sonophotocatalytic degradation of anionic dyes with nanoTiO 2 . Environ. Sc Technol 43: 473-479.

[24]. Wong Y, Yu J (1999) Laccase catalysed decolorisation of synthetic dyes. Water Res 33: 3512-3520.

[25]. Zabaniotou G, Stavropoulos V, Skoulou V (2008) Activated carbon from olive kernels in a two-stage process: Industrial improvement. Bioresour. Technol 99: 320-326.

\section{BIOGRAPHIES}

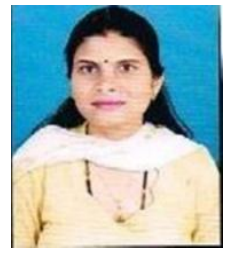

Ph.D. from Department of Polymer and Process Engineering, Indian Institute of Technology Roorkee, Saharanpur Campus,Saharanpur, with specialization of industrial pollution abatement. 